\title{
The Determinants Of European Bank Profitability
}

Christos K. Staikouras, (E-mail: cstaik@aueb.gr), Athens University of Economics and Business, Greece Geoffrey E. Wood, (E-mail: geowood@aol.com), City University Business School, United Kingdom

\begin{abstract}
The rate of return earned by a financial institution is affected by numerous factors. These factors include elements internal to each financial institution and several important external forces shaping earnings performance. The type of explanation would determine possible policy implications and ought to be taken seriously. This paper reviews the literature on bank performance studies and classifies the bank profitability determinants. The second part of the paper quantifies how internal determinants ("within effects" changes) and external factors ("dynamic reallocation" effects) contribute to the performance of the EU banking industry as a whole in 1994-1998. We construct OLS and fixed effects models, and the results provide a new perspective for understanding the impact of changes in competition on the performance of the EU banking industry. The estimation results suggest that the profitability of European banks is influenced not only by factors related to their management decisions but also to changes in the external macroeconomic environment. The results are in contrast to studies that have examined the structure-performance relationship for European banking and find a positive effect of the concentration and/or market share variables on bank profitability.
\end{abstract}

\section{Introduction}

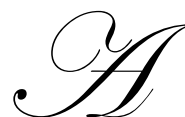

number of studies have examined bank performance in an effort to isolate the factors that account for interbank differences in profitability. These studies fall generally into severa categories. One group has focused broadly on the tie between bank earnings and various aspects of bank operating performance. A second set of studies has focused on the relationship between bank earnings performance and balance sheet structure. Another body of literature has examined the impact of some regulatory, macroeconomic or structural factors on overall bank performance.

The term bank structure is frequently used when referring to the characteristics of individual institutions. Individual bank characteristics such as the portfolio composition, and the scale and scope of operations, can affect the costs at which banks produce financial services. Market structure, measured by the relative size and number of firms, can influence the degree of local competition, and, by extension, the quality, quantity, and price of financial services ultimately available to bank customers.

\section{Literature Review}

Determinants of bank profitability can be split between those that are internal and those that are external. Internal determinants of bank profitability can be defined as those factors that are influenced by the bank's management decisions and policy objectives. Management effects are the results of differences in bank management objectives, policies, decisions, and actions reflected in differences in bank operating results, including profitability. Zimmerman (1996) found that management decisions, especially regarding loan portfolio concentration, were an important contributing factor in bank performance. Researchers frequently attribute good bank performance to quality management. Management quality is assessed in terms of senior officers' awareness and control of the bank's policies and performance.

Haslem $(1968,1969)$ computed balance sheet and income statement ratios for all the member banks of the US Federal Reserve System in a two-year study. His results indicated that most of the ratios were significantly related to profitability, particularly capital ratios, interest paid and received, salaries and wages. He also stated that a guide for improved management should first emphasise expense management, fund source 
management and lastly funds use management. Wall (1985) concludes that a bank's asset and liability management, its funding management and the non-interest cost controls all have a significant effect on the profitability record.

A number of studies have concluded that expense control is the primary determinant of bank profitability. Expense management offers a major and consistent opportunity for profitability improvement. With the large size and the large differences in salaries and wages, the efficient use of labour is a key determinant of relative profitability. Staff expenses, as conventional wisdom proposes, is expected to be inversely related to profitability because these costs reduce the 'bottom line' or the total operations of the bank. The level of staff expenses appears to have a negative impact on banks' ROA in the study of Bourke (1989). However, Molyneux (1993) found a positive relationship between staff expenses and total profits. As he suggests high profits earned by firms in a regulated industry may be appropriated in the form of higher payroll expenditures.

External determinants of bank profitability are concerned with those factors which are not influenced by specific bank's decisions and policies, but by events outside the influence of the bank. Several external determinants are included separately in the performance examination to isolate their influence from that of bank structure so the impact of the formers on profitability may be more clearly discerned.

A substantial amount of effort has been devoted to the determination of the relationship between banking structure and performance. Many studies in the banking literature and in the more general industrial organisation find a positive relationship between profitability and measures of market structure - either concentration or market share. Two competing hypotheses with regard to market structure and performance are the traditional structure-conduct-performance (SCP) hypothesis and the efficiency-structure (EFS) hypothesis. Both of them have has been used by international studies of bank performance. Short (1979), Bourke (1989), and Molyneux (1993) are using several independent variables related to characteristics both internal and external to bank's operations, in order to explain bank profitability either at an international or European level. For example, Bourke (1989), in the context of an international comparison of banks' profitability, devote a part of it to apply the methodology to a sample of seventeen French banks over the period 1972 to 1981.

The traditional structure-conduct-performance (SCP) hypothesis, asserts that banks are able to extract monopolistic rents in concentrated markets by their ability to offer lower deposit rates and charge higher loan rates. A related theory is the relative-market-power hypothesis (RMP) which asserts that only firms with large market shares and well-differentiated products are able to exercise market power in pricing these products and earn supernormal profits (Berger, 1995). Lloyd-Williams et.al. (1994) find support for the SCP hypothesis in the case of Spanish banks for the period 1986-1988. Yeats' (1974) key finding is that the structure-performance relation in banking may be best characterised by a dichotomous relationship. If this in fact occurs, banks which operate in market above some critical level of concentration earn monopoly profits while those in markets below the breakpoint earn competitive or near competitive profits. Finally, the pooled country estimates reported in Molyneux 's (1993) paper indicate that, over the period 1986 to 1989, collusive profits occur in the Belgian, French, Italian, Dutch and Spanish banking markets. His estimates also imply that collusive profits do not appear to accrue in non-EC banking markets.

A challenge to this interpretation is the efficient-structure (EFS) hypothesis. Market concentration is not a random event but rather the result in industries where some firms possess superior efficiency. This hypothesis states that efficient firms increase in size and market share because of their ability to generate higher profits, which usually leads to higher market concentration. To distinguish between the two hypotheses, past researchers have included market share as an independent variable, with a positive coefficient usually supporting the EFS hypothesis (Smirlock, 1985). Smirlock models bank profitability as a function of market share, concentration, and an interaction term between market share and concentration (as well as several control variables) for over 2,700 unit state banks. However, this conclusion depends on whether market share can be considered as a proxy for efficiency of larger firms rather than as a measure of market power. An obvious solution to this problem is to include a measure of efficiency directly in the model. A necessary condition for the EFS hypothesis to be true is that efficiency must be positively related to concentration and/or market share. Only recently, some authors [Berger and Hannan (1992), Goldberg and Rai (1996)] have tried to examine the implications of the EFS hypothesis regarding the effects of efficiency on market structure. Berger (1995) formulated models that included two measures of efficiency, X-efficiency and scale-efficiency, to test the 
structure-performance relationship. The positive relationship between profits and concentration is explained by lower costs achieved through either superior management or production processes.

Another variable used is some studies is the scale of regulation in several banking sectors. Jayaratne and Strahan (1998) find that operating costs and loan losses decrease sharply after states permit statewide branching and, to a lesser extent, interstate banking. The improvements following branching deregulation appear to occur because better banks grow at the expense of their less efficient rivals. Various studies have found that ownership characteristics may influence bank profitability. This is based on the view that management incentives differ under different forms of bank ownership [Short (1979), Bourke (1989), Molyneux (1993)].

The use of GDP growth as a variable does not feature extensively in the literature. However, Hoggarth et.al. (1998) conclude that the behaviour of real GDP fails to explain the greater variability of banking sector profits in the UK than in Germany. But they do not say that GDP variability did not affect profits, only that they could not use it to explain different UK/German banks performance. If this variable is not statistically significant in explaining profitability, then the conclusions of the authors are reinforced. Otherwise, the expected sign should be positive since higher growth implies both lower probabilities of individual and corporate default and an easiest access to credit.

The effects of inflation can be substantial and undermines the stability of the financial system and the ability of the regulator to control the solvency of financial intermediaries. Revell (1979) noted that variations in bank profitability can be strongly explained by the level of inflation. An important indirect influence on commercial banks lies in the impact of inflation on their customers and the consequent changes in the demand for different kinds of financial services. Unexpected rises of inflation cause cash flow difficulties for borrowers which can lead to premature termination of loan arrangements and precipitate loan losses. Furthermore, inflation is one of the main routes through which it is possible to affect the operations and margins of banks through interest rates. Although this phenomenon has long been recognised, it was first mentioned in the literature in terms of the 'endowment effect'. Hoggarth et.al. (1998) also mention that high and variable inflation has a major impact on bank earnings. Firstly, it creates great difficulty for the "assessment of loan decisions", since a loan arrangement which performs at the anticipated rate of inflation may turn out to be much more marginal if inflation is unexpectedly low and realised interest rates thus unexpectedly high. Uncertainty about future inflation may cause problems in planning and in negotiation of loans. Finally, high and variable inflation encourages bank financing investment in property markets, an investment strategy which may lead to market losses or great profitability according to the implemented monetary policy.

Performance is also influenced by numerous other forces that are frequently described as "demand" factors. While all demand factors cannot be identified or quantified, Kaufman (1965) believes that levels and changes in population and income may reasonably be assumed to be among the most important (also Yeats, 1974). Nelly and Wheelock (1997) conclude that state per capita income in US exerts a strong positive statistical effect on state bank earnings while income growth explains a relatively small amount of the variation in bank earnings. On the other hand, Heggestad (1977) found that per capita income does not affect bank profits. In any case, we suspect that per capita income may not be a good proxy for economic shocks that most directly affect bank earnings -for example, oil crises or commercial real estate crashes. A sharp downturn in a sector, such as real estate, could dramatically affect bank earnings without having a large impact on per capita income. Zimmerman (1996) found that regional employment conditions are a significant contributing factor for both community bank asset quality and ROA. Haslem (1968) found that the effects of location on profitability are not important (these effects are important only to bank managers and others). Tirtiroglou and Daniels (2000) suggest strongly that the regional heterogeneity of US banking geography and its temporal dynamics are important determinants of bank performance. On the other hand, Zimmerman (1996) suggests that location is an important factor in determining profitability. Prasad and Harker (1997) found that in the competitive environment of retail banking, neither IT capital not IT labour investments should make significant impacts on the firm's profitability. The results bear this hypothesis out: IT investment has zero or insignificant effect on bank profitability.

\section{Econometric Analysis and Data}

The literature generally comes to the conclusion that the appropriate functional form for testing is a linear function although there are dissenting opinions. Short (1979) investigated this question and concluded that linear functions produced as good results as any other functional form. The balance sheet and the income 
statement are obtained from the Fitch - International Bank Credit Analysis Ltd. (IBCA) Bankscope database. Accounting information are from the full spreadsheet and raw data files. This source provides data for the period 1992-1999. All of them have been consolidated on the $31^{\text {st }}$ of December of each year and are calculated in US\$. However, since the availability of data for early years (i.e. 1992, and 1993) and 1999 is short, we work with a balanced sample covering all the EU banking industries in the period 1994-1998. The main objective in choosing the particular sample period and their respective data is to utilise the most recent year-end financial data that are available in the new European economic and monetary environment that has been created.

The data was pooled to account for simultaneous consideration of intermproval movements and cross sectional differences. However, in our case with firm level data, there are typically large numbers of cross sectional units, but few time series observations on each firm. We therefore also approach panel techniques from the opposite direction, seeking to exploit the time series dimension of the data in order to achieve more powerful tests than are available based on pure cross sectional estimations. So, in addition to the pooled time series cross sectional regressions, the models also were estimated as a series of five year-by-year cross-sectional regressions, If the results are similar, this suggests that the findings are robust with respect to the pooling approach, the sample composition, and the period estimated. The analysis is extended to cover the different types of financial institutions i.e. commercial banks, savings banks, cooperative banks, and mortgage banks. Also we split the whole dataset in two parts; one covering large banks (total assets of over 10,000,000 milUS\$ in 1998) and small banks that include all the other financial institutions. The data were reviewed for reporting errors and other inconsistencies. Regression models using pooled time-series cross-sectional data for banking sectors across Europe will be utilised in our econometric analysis.

The data in the sample also include accounts for foreign bank subsidiaries. We do not omit these data on foreign bank subsidiaries for the following reasons. One of the major problems with concentration-profit analyses is defining the extent of the market. As there is no sub-market data officially available for different European countries, we choose the simplest and broadest market definition - total banking sector assets in each particular country. As we aim to evaluate banking industry performance across different European markets, and as our market definition includes the assets of both domestic and foreign banks, it seems justifiable to include information on these types of banks in our analysis. The majority of individual bank data for Luxembourg and the United Kingdom are on foreign bank subsidiaries.

The literature review supports that many different determinants may influence profitability. However, it is difficult to tell whether all are significant factors in bank performance, and if they are, which their relative importance is. With this limitation in mind the study now moves to exploring these relationships at the individual bank level. The underlying assumption of the empirical analysis is that the measure of the profitability reflects management efforts to maximise shareholder wealth and not engage in expense preference behaviour. The underlying economic structure which determines the profitability of the bank indicates that profit is determined simultaneously with overall bank risk and the composition of the bank's balance sheet; the appropriate structural model must provide for this simultaneity. Further, the structural model may include variables which capture the influence the risk-return preferences of the bank management (ownership), as well as any element of the market, regulatory and organisational structures may have on the return and cost attributes of the assets and liabilities selected by the bank. The whole process is not an easy one. Haslem (1969) managed to explain as much as 77 per cent of the total variation in profitability for each of his examined years by using fourteen explanatory variables (two qualitative and twelve ratios) to do it.

In banking, output and productivity are difficult to be estimated due to definitional problems, joint products, and conceptual issues about which services a bank actually provides. To avoid this problem, researchers interested in the performance of the banking industry have often looked at profitability. Using accounting data has some appeal. First, market data are typically available only for the largest firms in an industry, so they clearly are more limited than accounting data. In addition, regulators rely heavily on accounting figures in their evaluation of a firm's financial condition. The earnings quality of European banks will be examined through the use of the return on assets (ROA). Similar are the results if we use the return on equity (ROE). In both cases the profits are taking before tax to cover the different taxation systems that are implemented across Europe. For example the tax figure reported on a firm's annual statements may include tax credits or carry-forwards that do not pertain to the current year's performance.

As reported earlier, the literature review on bank performance studies suggests that bank profitability is determined by factors both internal and external to the bank. Since the performance measure is not risk-adjusted, 
we employ four variables to account for firm-specific risk. The loan-to-assets ratio $(L A)$ provides a measure of risk since loans are riskier and have a greater expected return than other bank assets, like government securities. Thus, one would expect a positive relationship between this variable and the performance measure. It could be the case, however, that banks that are rapidly increasing their loan books have to pay a higher cost for their funding requirements and this could reduce the positive impact on profitability.

The equity-to-assets ratio (EA) is also included as a measure of the overall capital strength. The ratio is a measure of capital adequacy, and should capture the general average safety and soundness of the financial institutions. A deterioration of the equity-to-assets ratio indicates either an increase in debt financing of banks' total assets (while holding total assets constant), or a decline in banks' total assets (while holding total equity constant), or both over time and space. Irrespectively, this is an increase in banks' risk, and potentially, in banks' cost-to-capital. The theory of capital structure states that a higher use of debt (equity) financing within a certain range, called the target capital structure, might actually reduce (increase) firms' cost of capital. Thus a positive (negative) coefficient estimate for equity-to-assets indicates an efficient (inefficient) management of banks' capital structure.

According to some authors the equity (capital)-to-assets ratio is negatively related to the total revenue dependent variable, since lower capital ratios should lead to higher bank revenues ${ }^{1}$. Accounting to conventional wisdom in banking, a higher capital-to-assets ratio is associated with lower profitability. A higher capital-toassets ratio tends to reduce the risk of equity and therefore lowers the equilibrium expected return on equity required by investors. In addition, a higher equity-to-assets ratio lowers after tax earnings by reducing the tax shield provided by the deductibility of interest payments. Moreover, the reduced risk from a higher capital ratio may depress earnings by lowering the value of access to federal deposit insurance (as is the case in the United States) that at best imperfectly prices risk. Despite these arguments, the data on banks in 1990s tell a very different story. Book values of capital-to-assets ratio and profitability are positively related, and this relationship is both statistically and economically significant. According to Berger (1995) there are a number of potential explanations for the positive capital-earnings relationship. An increase in capital may raise expected earnings by reducing the expected costs of financial distress including bankruptcy. Also, an increase in earnings may raise the capital ratio, provided that marginal earnings are not fully paid out in dividends. Higher capital-to-assets ratio may also cause higher profitability if the higher capital reduces risk-related barriers to entry or expansion into some profitable product lines. Banks that increase capital and reduce their risks may be better able to avoid issuing off-balance-sheet guarantess, such as loan commitments and standby letters of credit. Safer banks may also be able to borrow uninsured funds more easily to pursue high revenue on-balance-sheet investment opportunities as they arise.

The provisions for loan losses-to-total loans (PLL/TL) ratio provides a measure of the capital risk. In our analysis we have the problem that the dataset does not provide figures for that ratio in Germany. So, the sample is much smaller (especially for savings and cooperative banks) compared with the case that we do not include the measure of capital risk. However, we prefer to present initially the results with the participation of that variable in order to cover the whole set of possible risks that a bank can face. Unfortunately we do not have enough data to include other credit risk measures, as are the net charge offs or the non-performing loans to total loans. Finally, as a measure of interest rate risk we include the gap-to-assets ratio (Gap) which is defined as the difference between interest rate sensitive assets and interest rate sensitive liabilities divided by total assets of each financial institution.

The concentration ratio and the bank market share variables are calculated on the basis of the size of the national markets, i.e. total banking sector assets. Concentration is measured country by country in terms of assets, either by the 3-firm concentration ratio (conc) or the Herfindahl index $(\mathrm{H})^{2}$. The 3 -firm concentration ratio for each country is defined as the sum of the market shares of the 3 firms with the largest market shares, where market share is measured in terms of the book value of assets. Firm-specific market share (MSH), defined as the bank's assets divided by total value of assets of all banks in a given country and in Fitch's Bankscope. These measures are used to capture for both the traditional concentration-performance relationship and the efficient hypothesis.

\footnotetext{
${ }^{1}$ Molyneux (1993) states that: "As lower [equity-to-assets] ratios suggest a relatively risky position, one would expect a negative coefficient on this variable, although it could be the case that high levels of equity suggest that the cost of capital is relatively cheap and therefore this variable may have a positive impact on profitability".

${ }^{2}$ This index is calculated as the sum of the squares of the market shares of the several banks in a country.
} 
Empirical industrial organisation literature has shown that the distribution of firm sizes within many industries and countries can often be approximated by various skewed distributions of which the most widely used is the lognormal. The size effect is captured by the natural logarithm of the total assets for each financial institution (lnassets). The log of assets is used instead of assets in order to reduce the scale effect. This variable controls for cost differences related to bank size and for the greater ability of larger banks to diversify. The first factor would lead to positive coefficient for profitability if there are significant economies of scale and the second to negative coefficients if increased diversification leads to lower risk and thus lower required returns.

Quite sophisticated measures of both scale efficiency and X-efficiency are discussed in the literature (Berger and Hannan, 1992). In general, these require estimating a cost function for banks, which is feasible only for a sufficiently long time series. For the purpose of the analysis here, we have decided to follow a simpler approach and measure inefficiency as the ratio of overheads, which is available as a cost item in the income statement to total assets $(O A)$ in each year and for each bank. We expect an inverse relationship with profitability.

A last group hypotheses concerns macroeconomic conditions. The evidence suggests that bank performance is sensitive to macroeconomic conditions despite the trend in the industry towards greater geographic diversification and greater use of financial engineering techniques to manage risk. We also introduce the level of interest rates $(I R)$ and their variability $(V A R)$. We use the three months interbank rate for each European country from Datastream (we do not have data only for Luxembourg). Drawing data for all countries from the same source ensures comparability across the measures. The variability is measured as the standard deviation of weekly rates around their annual average ${ }^{3}$.

Finally we include the growth rate of the GDP $(d G D P)$ and of the gross personal income (dGPI) for each EU country. Both of them affect numerous factors related to the supply and demand for loans and deposits. One might expect bank profitability to be driven by real GDP for a number of reasons. First, bank asset quality will depend on the position in the cycle. Loan loss provisions will be related to default risks. These will be greater in downturns than in upturns, so that bank profitability will be positively correlated with GDP growth. One can also view GDP as measuring the size of the market in which banks operate. In upturns, there will be higher demand for bank credit than in downturns. If the number of banks operating across the cycle is constant, one would, under conditions of imperfect competition, expect bank profitability to be positively related to market size as measured by GDP. However, the coefficient may also be negative because countries with higher GDP or GPI are assumed to have a banking system that operates in a mature environment resulting in more competitive interest and profit margins (see also Goldberg and Rai, 1996). These data have been taken from national statistics published in the IMF's International Financial Statistics and the OECD. These factors could well be important for the experience of EU banks, which since 1994 have operated under conditions of relative high GDP growth and falling interest rates. Ireland shows the highest growth rates of real GDP, which has had an average growth rate of more than three times the average. Greece and Portugal are followed.

The sample includes 685 European banks (138 large banks and 547 small banks) (Table 1). If we do not include the loan loss provisions ratio the sample comprises of 2,162 European banks because, as we have already mentioned above, we include the German banks that do not provide the above mentioned ratio.

\footnotetext{
${ }^{3}$ The level of interest rates is used instead of the rate of inflation in order to avoid multicollinearity problems.
} 
Table 1: Number of banks in the sample

\begin{tabular}{|l|c|c|c|}
\hline \multicolumn{1}{|c|}{ Country } & Large banks & Small banks & $\begin{array}{c}\text { Total number of } \\
\text { banks }\end{array}$ \\
\hline Belgium & 7 & 18 & 25 \\
\hline Denmark & 5 & 56 & 61 \\
\hline Greece & 4 & 4 & 8 \\
\hline France & 34 & 176 & 66 \\
\hline UK & 15 & 51 & 8 \\
\hline Ireland & 3 & 5 & 12 \\
\hline Sweden & 9 & 3 & 188 \\
\hline Italy & 25 & 163 & 1 \\
\hline Germany & 1 & 0 & 20 \\
\hline Portugal & 7 & 13 & 61 \\
\hline Spain & 19 & 42 & 6 \\
\hline Finland & 4 & 2 & 19 \\
\hline Netherlands & 5 & 14 & $\mathbf{6 8 5}$ \\
\hline Totals & $\mathbf{1 3 8}$ & $\mathbf{5 4 7}$ & \\
\hline
\end{tabular}

Table 2 provides summary statistics for the variables that are used in the analysis. The profit rates have a mean of $0.9297 \%$ of total assets and a standard deviation of $1.2726 \%$. The mean value of the loans-to-assets ratio is $54 \%$ but with the standard deviation approaching $20 \%$. Equity is, on average, $7.7 \%$ of total assets but with a significant variation (3.92\%). The overheads are $3 \%$ of total assets. The $d G D P$ and the $d G P I$ have similar levels for their mean values, but the $d G D P$ has much higher variability. Worth mentioning is the high variability of the loan loss provisions to total loans and the market share variable (2.64\% and $11.08 \%$ respectively). Also, the return on assets has a negative skewness, while OA significant positive kurtosis.

Table 2: Descriptive Statistics

\begin{tabular}{|l|l|l|l|l|l|l|l|}
\hline & \multicolumn{1}{|c|}{ mean } & \multicolumn{1}{c|}{ St. dev. } & \multicolumn{1}{c|}{ min } & \multicolumn{1}{c|}{ max } & \multicolumn{1}{c|}{ Var. } & \multicolumn{1}{c|}{ skew. } & \multicolumn{1}{c|}{ kurt. } \\
\hline ROA & 0.9297 & 1.2746 & -22.6530 & 14.6611 & 1.6245 & -4.7911 & 75.2807 \\
\hline Lnassets & 14.5790 & 1.8978 & 9.3393 & 20.3752 & 3.6019 & 0.3907 & 0.0901 \\
\hline LA & 54.0069 & 19.2529 & 0.3110 & 99.5503 & 370.6758 & 0.0861 & -0.1490 \\
\hline Gap & 0.0603 & 0.0485 & -0.1831 & 0.3796 & 0.0024 & 0.1074 & 1.3588 \\
\hline EA & 7.7217 & 3.9219 & -11.2884 & 38.4245 & 15.3816 & 0.9458 & 1.6346 \\
\hline OA & 2.9963 & 1.4034 & 0.0398 & 15.295 & 1.9696 & 0.8463 & 4.1734 \\
\hline LLP/TL & 1.1386 & 2.6440 & -37.0154 & 77.7832 & 6.9922 & 9.7118 & 271.7168 \\
\hline MSH & 2.4319 & 11.0807 & 0.0015 & 179.0446 & 122.7822 & 9.4619 & 110.2415 \\
\hline H & 786.6545 & 512.9612 & 249.2857 & 3637.543 & 263129.2 & 1.9231 & 3.3595 \\
\hline INT & 6.1488 & 2.4173 & 3.0754 & 27.2734 & 5.8432 & 2.0506 & 12.9465 \\
\hline DEV & 0.5234 & 1.1030 & 0.0484 & 22.2561 & 1.2388 & 17.5549 & 337.8466 \\
\hline DGDP & 4.8098 & 16.3800 & -37.2823 & 106.4748 & 268.3048 & 3.9170 & 24.3683 \\
\hline DGPI & 4.6992 & 1.9183 & -7.3847 & 14.0852 & 3.6800 & 1.3091 & 2.4003 \\
\hline
\end{tabular}


Table 3 presents the correlation matrix for the several variables. We will select initially independent variables in the order of highest correlation with the dependent variable, and the lowest correlation with any independent variable previously selected. We find a significant positive correlation of ROA with the Gap and EA variables and negative with the LLP/TL variable. Also there is a strong negative correlation of assets with EA and OA and positive with MSH, as well as a positive one of gap with EA, of EA with OA, and a negative one of LA with EA, and of IR with DEV and dGPI (all of them expected).

Table 3: Correlation Matrix

\begin{tabular}{|l|c|c|c|c|c|c|c|c|c|c|c|c|c|}
\hline & $\begin{array}{c}\text { RO } \\
\text { A }\end{array}$ & Lnas & LA & Gap & EA & OA & LLP & $\begin{array}{c}\text { MS } \\
\text { H }\end{array}$ & H & IR & DEV & dGD & $\begin{array}{c}\text { dGP } \\
\text { I }\end{array}$ \\
\hline ROA & 1.00 & & & & & & & & & & & & \\
\hline Lnas & -0.12 & 1.00 & & & & & & & & & & & \\
\hline LA & 0.09 & -0.03 & 1.00 & & & & & & & & & & \\
\hline Gap & $\mathbf{0 . 3 2}$ & -0.23 & 0.06 & 1.00 & & & & & & & & & \\
\hline EA & $\mathbf{0 . 3 9}$ & $\mathbf{- 0 . 5 1}$ & $\mathbf{- 0 . 3 9}$ & $\mathbf{0 . 6 9}$ & 1.00 & & & & & & & & \\
\hline OA & 0.11 & $\mathbf{- 0 . 4 1}$ & 0.06 & 0.10 & $\mathbf{0 . 3 7}$ & 1.00 & & & & & & & \\
\hline LLP & $\mathbf{- 0 . 4 3}$ & -0.09 & -0.10 & -0.01 & -0.01 & 0.12 & 1.00 & & & & & & \\
\hline MSH & 0.01 & $\mathbf{0 . 4 3}$ & -0.01 & -0.03 & -0.16 & -0.14 & -0.04 & 1.00 & & & & & \\
\hline H & 0.08 & -0.02 & 0.02 & 0.01 & 0.04 & -0.12 & -0.03 & 0.11 & 1.00 & & & & \\
\hline IR & 0.08 & -0.02 & -0.18 & 0.07 & 0.16 & 0.14 & 0.02 & 0.04 & -0.07 & 1.00 & & & \\
\hline DEV & 0.02 & 0.01 & -0.07 & -0.01 & 0.01 & 0.03 & 0.03 & 0.03 & 0.16 & $\mathbf{0 . 5 5}$ & 1.00 & & \\
\hline $\begin{array}{l}\text { DGD } \\
\text { P }\end{array}$ & -0.08 & -0.04 & -0.01 & -0.01 & 0.01 & 0.02 & 0.03 & 0.02 & 0.12 & 0.19 & 0.04 & 1.00 & \\
\hline $\begin{array}{l}\text { DGP } \\
\text { I }\end{array}$ & 0.14 & -0.08 & 0.00 & 0.07 & 0.20 & 0.08 & -0.02 & 0.05 & 0.22 & $\mathbf{0 . 4 1}$ & 0.28 & 0.23 & 1.00 \\
\hline
\end{tabular}

\section{Empirical Results}

In order to test for the empirical relevance of the hypotheses regarding the causes of bank profitability, we adopt a multiple regression framework to analyse the panel data set that has been constructed. The basic equation we have worked with is:

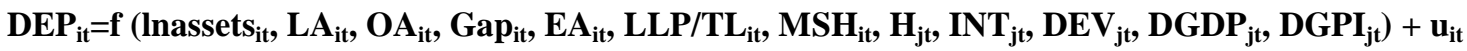
where $\mathrm{i}$ refers to an individual bank, $\mathrm{t}$ refers to time, and $\mathrm{j}$ refers to the country in which bank i operates. $\mathrm{DEP}_{\mathrm{it}}$ is the dependent variable and is the observation of a particular bank in a particular year.

At each stage of model building and for each group of regression results, we perform the regression with all variables included and we examine the results. Only the fixed effects' results are presented with all variables included since they are the best estimates (Table 4). The sample is comprised of 3,425 observations. The explanatory power of the model, the R-squared, is at the satisfactory level of 0.68 . The standard error of the regression is 0.7169 . It also seems that we do not have heteroscedasticity problems, as we conduct the Lagrange multiplier $(\mathrm{LM})^{4}$ test for heteroscedasticity. Since the Durbin-Watson statistic is 1.78 , one may assume that there is no first-order autocorrelation, either positive or negative. All the variables are significant at the 5\% level in the regression with the expected sign. Based on a Hausman test we can conclude that of the two alternatives (fixed versus random effects), the fixed effects estimator is the appropriate choice. The market structure variables do not have any influence, while the change of the GDP and the level of interest rates have significant negative and positive effects respectively (their t-statistics are -8.4756 and 4.5202 respectively). All other variables have significant influence with the expected signs.

\footnotetext{
${ }^{4}$ The assumptions of homoscedastic residual variance is often violated by the use of cross-sectional data. To investigate whether there is evidence of heteroscedasticity in the residual variance we use the Lagrange Multiplier (LM) test. The LM test is performed by regressing the residuals into the predicted values from which they were obtained. Calculating $n R^{2}$, where $n$ is the sample size and $R^{2}$ obtained from this regression gives the test statistic. Its distribution will be chi-squared with $S$ degrees of freedom, where $S$ is the number of restrictions in the model. The critical chi-square values are 3.84146 (at the 5\% level) and 6.63490 (at the 10\% level). Values below this would reject the null hypothesis of heteroscedastic residual variance.
} 
Table 4: Within (fixed effects) estimates

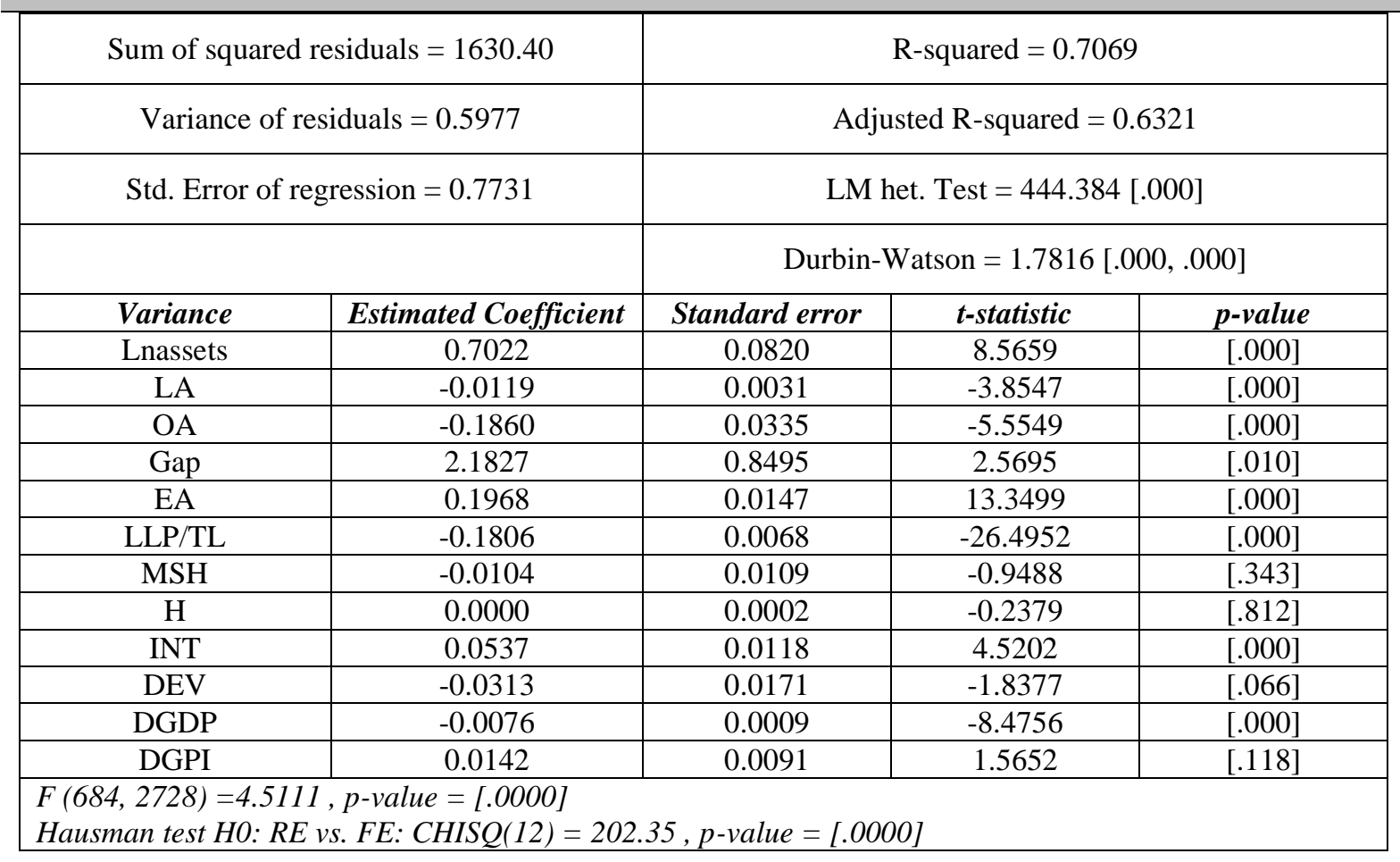

\section{Size effects}

We split the banks according to the cut-off point we have defined for the size of the financial institutions i.e. the large banks have total assets of over US\$10,000bn in 1998. In this case the two sub-samples comprise from 138 large banks (or 690 observations) and 547 small banks (or 2,735 observations) respectively. We introduce all variables in the model (Table 5). All variables are significant with the expected sign. The tstatistics are much more significant in the case of small banks. However, the R-squared is much higher for large banks, and the sum of the squared residuals and their variance smaller. The interesting points are that the size variable has negative impact on large banks, while a significant positive one on small banks, and the level of interest rates has a negative impact on large banks and positive on small banks. This result gives support to the recent papers that mention the diseconomies of scale that exist from a level of size upwards. Growing banks may face diminishing marginal returns so average profits would decline with size. Information advantage and the enforcement power gain from size is significant for small banks. 
Table 5: Within (fixed effects) estimates for large and small banks

\begin{tabular}{|c|c|c|c|c|}
\hline \multicolumn{2}{|c|}{$\begin{array}{c}\text { Sum of squared residuals } \\
46.7127(1473.74)\end{array}$} & \multicolumn{3}{|c|}{$\begin{array}{c}\text { R-squared } \\
0.8316(0.7205)\end{array}$} \\
\hline \multicolumn{2}{|c|}{$\begin{array}{c}\text { Variance of residuals } \\
0.0865(0.6773)\end{array}$} & \multicolumn{3}{|c|}{$\begin{array}{c}\text { Adjusted R-squared } \\
0.7851(0.6488) \\
\end{array}$} \\
\hline \multicolumn{2}{|c|}{$\begin{array}{c}\text { Standard error of regression } \\
0.2941(0.8230)\end{array}$} & \multicolumn{3}{|c|}{$\begin{array}{c}\text { LM heteroscedasticity test } \\
2.8639[.091](352.007[.000])\end{array}$} \\
\hline & & \multicolumn{3}{|c|}{$\begin{array}{c}\text { Durbin-Watson test } \\
1.5901[.000](1.7532[.000])\end{array}$} \\
\hline Variance & Estimated Coefficient & Standard error & t-statistic & p-value \\
\hline Lnassets & $-0.1777(0.7688)$ & $0.0743(0.1041)$ & $-2.3914(7.3857)$ & {$[.017]([.000])$} \\
\hline LA & $0.0069(-0.0147)$ & $0.0031(0.0036)$ & $2.2368(-4.1084)$ & {$[.026]([.000])$} \\
\hline Gap & $2.0573(3.2008)$ & $0.7203(1.0234)$ & $2.8563(3.1276)$ & {$[.004]([.002])$} \\
\hline EA & $0.0172(0.2213)$ & $0.0141(0.0173)$ & $1.2205(12.7822)$ & {$[.223]([.000])$} \\
\hline $\mathrm{OA}$ & $-0.0850(-0.1991)$ & $0.0483(0.0376)$ & $-1.7585(-5.2955)$ & {$[.079]([.000])$} \\
\hline LLP/TL & $-0.0154(-0.2083)$ & $0.0067(0.0079)$ & $-2.2793(-26.3182)$ & {$[.023]([.000])$} \\
\hline MSH & $-0.0056(0.4480)$ & $0.0043(0.1661)$ & $-1.3013(2.6971)$ & $[.194](.007])$ \\
\hline $\mathrm{H}$ & $-0.0001(0.0000)$ & $0.0001(0.0002)$ & $-1.0532(0.4261)$ & {$[.293]([.670])$} \\
\hline INT & $-0.0276(0.0663)$ & $0.0102(0.0147)$ & $-2.7231(4.5001)$ & {$[.007]([.000])$} \\
\hline DEV & $0.0273(-0.0448)$ & $0.0104(0.0249)$ & $2.6304(-1.7979)$ & {$[.009]([.072])$} \\
\hline DGDP & $-0.0044(-0.0079)$ & $0.0010(0.0010)$ & $-4.0787(-7.8128)$ & {$[.000]([.000])$} \\
\hline DGPI & $0.0320(0.0136)$ & $0.0078(0.0109)$ & $4.0957(1.2478)$ & {$[.000]([.212])$} \\
\hline \multicolumn{5}{|c|}{$\begin{array}{l}\mathrm{F}(137,540)=10.598, \mathrm{p} \text {-value }=[.0000] \\
F(546,2176)=4.6695, p \text {-value }=[.0000] \\
\text { Hausman test } \mathrm{H} 0: \mathrm{RE} \text { vs. FE: } \mathrm{CHISQ}(12)=51.058, \mathrm{P} \text {-value }=[.0000] \\
\text { Hausman test HO: RE vs. } F E: \text { CHISQ }(12)=204.49, \text { P-value }=[.0000]\end{array}$} \\
\hline
\end{tabular}

Note: Funds with italics refer to small banks; otherwise, large banks.

\section{Type effects}

Finally, we split the banks according to their type. The four categories are those of commercial, cooperative, savings and mortgage banks. We conclude with 356 commercial banks, 135 savings banks and 151 co-operative banks. We do not include the mortgage banks since the number of institutions in that category is small (only 43 financial institutions are mortgage banks). We should repeat at this point that the number of savings and co-operative banks has been reduced since we do not have available data for the loan loss provisions of the German banks (where most of the savings and cooperative banks are established) and our sample is balanced. The reported R-squared is higher for cooperative banks (0.82), while it is 0.72 for commercial banks and 0.65 for savings banks. However, the standard error of the regression is the highest one for commercial banks. All the variables are significant with the expected sign. The Gap variable is more significant for savings banks (the t-statistic is 7.0490), while the EA variable is more significant for commercial banks (the t-statistic is 9.5187). For savings banks, the sign for EA is negative but insignificant. The LLP/TL is more significant with negative effect on profitability for commercial and cooperative banks (the t-statistics equal -24.1567 and -12.2459 respectively). From the Hausman test, it seems that the random effects may give better estimates in the case of co-operative banks. However the results, even with the implementation of the random effects model, are the same. What we observe is a significant positive effect of the level of interest rates on profitability, while the variability of interest rates is significant but positive for the savings banks (the t-statistic is 6.0219). Finally, the GDP growth is significant and negative in the case of commercial and savings banks, and the GPI growth significant and positive for co-operative banks.

\section{Concluding Remarks}

We believe that testing for the robustness of banks' performance over time and space should shed light on policy debates, and on the assessment of banks' performance. In addition, we believe that our work has some relevance and importance for the ongoing wave of consolidation and restructuring in the European banking markets as an outcome of the Monetary Union. A linear function of a multiple regression equation, on a pooled 
cross section time series sample, is utilised to test the effects of firm and market specific variables on bank profitability. A number of studies have examined bank performance in an effort to isolate the factors that account for interbank differences in profitability. These factors are either internal or external. Individual bank characteristics such as the portfolio composition, and the scale and scope of operations, can affect the costs at which banks produce financial services. Market structure, measured by the relative size and number of firms, can influence the degree of local competition, and, by extension, the quality, quantity, and pricing of financial services ultimately available to bank customers.

This paper quantifying how internal changes ("within effects" changes) due to changes in balance composition and external factors ("dynamic reallocation" effects) due to market share changes and the macroeconomic environment contribute to the performance of the EU banking industry as a whole from 1994 to 1998. The decomposition identifies and measures both of these two broad factors that jointly determine the performance of the EU banking industry. This distinction is important as failure to count for the dynamic reallocation effects can create mistaken impressions about the underlying strength of the industry.

We perform cross-sectional time series regressions and year-by-year cross sectional regressions. The use of pooled data allows us better to control for the effects of missing or omitted variables. Rather than including other bank-varying variables, a comparison of the results for the OLS regressions with the fixed-effect models over banks can indicate whether the omission of bank-varying variables in the pooled OLS regressions produce biased results, and whether these biases arises.

The estimation results suggest that the profitability of European banks is influenced not only by factors related to their management decisions but also to changes in the external macroeconomic environment. Equity to assets ratio has consistently the same sign and level of significance suggesting that banks with greater levels of equity are relatively more profitable. The loans to assets ratio appears to be inversely related to banks return on assets. This implies that banks which have large non-loan earning assets are more profitable than those which depend more heavily on assets. The funds gap ratio is significantly positive, and the proportion of loan loss provisions to total loans significantly negative. Also, the results are in contrast to studies that have examined the structure-performance relationship for European banking and find a positive effect of the concentration and/or market share variables on bank profitability. In our case, not only the traditional structure-conduct-performance hypothesis, but also the efficient hypothesis are not supported. The MSH variable is not significantly different from zero in either regression. In fact, its sign tends to be unstable and is found to be negative in some regressions. However, if we exclude the loan loss reserves' variable the concentration ratio seems to be significant but negative. The level of interest rates have a positive effect, while the variability of the interest rates and the growth of GDP rates negative.

We have to point out that there are some measurement issues with the MSH variable, since it takes the share of the value of assets of bank over the total market value of the banks in each country, which are included in the Bankscope dataset. It therefore is influenced by how many banks in each country are reporting balance sheet data to Fitch-IBCA. This issue should be addresses in future work. A limitation of the analysis may be related to the specification of the functional form of the estimating equation. Linear functions may mispecify the nature of the relationship between profitability and the several internal and external determinants and bias the results. The type of explanation for the level of profitability would determine possible policy implications and ought to be taken seriously. Since very little empirical work has been undertaken investigating the competitive behaviour of European banking systems, an empirical investigation like the one conducted above may yield insights that could be of interest to academics, bankers, and policy makers.

\section{References}

1. Berger, A. (1995). The relationship between capital and earnings in banking. Journal of Money, Credit and Banking 27 (2): 432-456.

2. Berger, A. and HANNAN, T. (1992). The price-concentration relationship in banking: a reply. The Review of Economics and Statistics 74: 376-379.

3. Berger, A., and MESTER, T. (1998). The efficiency cost of market power in the banking industry: a test of the "quiet life" and related hypotheses. Review of Economics and Statistics (80): 454-465.

4. Bourke, P. (1989). Concentration and other determinants of bank profitability in Europe, North America and Australia. Journal of Banking and Finance 13: 65-79. 
5. $\quad$ Fraser, D. and Rose, P. (1971). More on banking structure and performance: the evidence from Texas. Journal of Financial and Quantitative Analysis VI (1): 601-614.

6. Golbert, L. and Rai, A. (1996). The structure-performance relationship for European banking. Journal of Banking and Finance 20: 745-771.

7. Haslem, J. (1968). A statistical analysis of the relative profitability of commercial banks. Journal of Finance 23: 167-176.

8. Haslem, J. (1969). A statistical estimation of commercial bank profitability. Journal of Business 42: 2235 .

9. Heggestad, A. (1977). Market structure, risk and profitability in commercial banking. The Journal of Finance XXXII (4): 1207-1216.

10. Heggestad, A. and MINGO, J. (1976). Prices, nonprices, and concentration in commercial banking. Journal of Money, Credit, and Banking 8: 107-117.

11. Hoggarth, G., Milne, A. and Wood, G. (1998). Financial innovation and financial stability: some lessons from Germany and the UK. Financial Stability Review, Bank of England.

12. Jayaratne, J. and Strahan, P. (1998). Entry restrictions, industry evolution, and dynamic efficiency: evidence from commercial banking. Journal of Law and Economics XLI: 239-270.

13. Kaufman, G. (1965). Bank market structure and performance: the evidence from Iowa. Southern Economic Journal 32: 429-439.

14. Kwast, M. and ROSE, J. (1982). Pricing, operating efficiency, and profitability among large commercial banks. Journal of Banking and Finance 6: 233-254.

15. Lloyd-WILliAMS, M., Molyneux, P. and Thornton, J. (1994). Market structure and performance in Spanish banking. Journal of Banking and Finance 18: 433-443.

16. Molyneux, P. (1993). Market structure and profitability in European banking. Institute of European Finance, University College of North Wales, Research Paper 9.

17. Molyneux, P. (1999). Increasing concentration and competition in European banking: the end of antitrust? Federal Reserve Bank of Chicago, Economic Perspectives 4 (1): 127-133.

18. Neely, M.C. and Wheelock, D. (1997). Why does bank performance vary across states? Federal Reserve Bank of St. Louis 79 (2): 29-40.

19. Prasad, B., and Harker, P. (1997), Examining the contribution of information technology toward productivity and profitability in U.S. retail banking. The Wharton School, University of Pennsylvania, Financial Institutions Center 97-09.

20. Revell, J. (1979). Inflation and financial institutions. (The Financial Times Ltd., London).

21. Short, B. (1979). The relation between commercial bank profit rates and banking concentration in Canada, Western Europe, and Japan. Journal of Banking and Finance 3: 209-219.

22. Smirlock, M. (1985). Evidence on the (non) relationship between concentration and profitability in banking. Journal of Money, Credit, and Banking 17 (1): 69-83.

23. Tirtiroglou, D., and Daniels, K. (2000). Does relaxing state-level regulations improve the productivity growth of US commercial banks? EFMA Annual Meeting, Athens 2000.

24. Wall, L.D. (1985). Why are some banks more profitable than others? Journal of Bank Research 15 (4): 240-256.

25. Yeats, A. (1974). Further evidence on the structure-performance relation in banking. Journal of Economics and Business 26: 95-100.

26. Zimmerman, G. (1996). Factors influencing community bank performance in California. Federal Reserve Bank of San Francisco 1: 26-41. 